\title{
PROFIL PEMAHAMAN MAHAMAHASISWA DALAM MENGAPLIKASIKAN METODE PENYELESAIAN SISTEM PERSAMAAN LINIER
}

\author{
Restu Lusiana \\ IKIP PGRI MADIUN \\ restu.matedu.yahoo.com
}

\begin{abstract}
Abstrak
Penelitian ini bertujuan untuk mengetahui seberapa besar mahasiswa memahami pengaplikasian metode penyelesaian sistem persamaan linier. Jenis penelitian yang digunakan adalah deskriptif kualitatif. Teknik pengambilan subyek dilakukan dengan cara memberikan tes kemampuan kognitif. Teknik pengumpulan data dalam penelitian ini diperoleh berdasarkan hasil tes, wawancara, dan dokumentasi. Teknik analisis data dalam penelitian ini terdiri dari reduksi data, penyajian data, dan penarikan kesimpulan serta verifikasi. Teknik keabsahan data dalam penelitian ini dengan triangulasi data. Hasil penelitian ini adalah (1) Mahasiswa kategori tinggi menunjukkan bahwa mahasiswa berkecenderungan memiliki pemahaman yang baik saat mengaplikasikan metode dalam menyelesaikan masalah sistem persamaan linier. Mahasiswa dapat memberikan penjelasan penyelesaian masalah dengan tepat, (2) Mahasiswa kategori sedang menunjukkan bahwa mahasiswa berkecenderungan memiliki pemahaman yang cukup baik saat mengaplikasikan metode dalam menyelesaikan masalah sistem persamaan linier. Secara umum mahasiswa dapat memberikan penjelasan penyelesaian masalah, tetapi belum tepat, dan (3) Mahasiswa kategori rendah menunjukkan bahwa mahasiswa berkecenderungan memiliki pemahaman yang kurang baik saat mengaplikasikan metode dalam menyelesaikan masalah sistem persamaan linier. Secara umum mahasiswa tidak dapat memberikan penjelasan dalam penyelesaian masalah dengan tepat.
\end{abstract}

Kata Kunci: Pemahaman Mahasiswa, Mengaplikasikan, Metode Penyelesaian, Sistem Persamaan Linier.

\section{PENDAHULUAN}

Profil pemahaman mahasiswa adalah gambaran mahasiswa tentang pemahamannya menguasai materi dan menerapkannya dalam menyelesaikan masalah dalam matematika. Dalam hal ini mahasiswa masih mengalami kesulitan untuk mendiskripsikan atau mengambarkan apa yang telah di pelajarinya, padahal untuk mengikuti perkembangan ilmu sesuai dengan zaman sekarang dibutuhkan pemahaman yang sangat mendalam agar para mahasiswa tidak mudah tertipu dengan berbagai macam masalah yang dihadapi dan dapat menyelesaikannya dengan mudah. Penting sekali menanamkan pemahaman suatu materi pada diri sejak awal pertemuan, agar mahasiswa 
merasa mudah untuk menyelesaikan masalah.

Mengaplikasikan metode merupakan salah satu cara untuk menyelesaikan masalah atau soal-soal matematika, mahasiswa harus mampu menguasai metode dan mengaplikasikannya dalam suatu masalah. Tapi pada kenyatannya mahasiswa masih cenderung sulit untuk mengaplikasikan rumus untuk menyelesaikan masalah, karena mereka cenderung menghafal rumus yang sebenarnya harus dipahami secara lebih dalam, sehingga mahasiswa mampu menerapkan dalam berbagai soal matematika.

Menurut Anwar Sutoyo (2012: 34) Pemahaman individu adalah suatu cara untuk memahami, menilai, atau menaksir karakteristik, potensi, dan atau masalah-masalah (gangguan) yang ada pada individu atau sekelompok individu. Cara-cara yang digunakan itu mencakup observasi, interview, skala psikologis, daftar cek, inventory, tersproyeksi, dan beberapa macam tes. Pemahaman atau penilaian itu dimaksudkan untuk kepentingan pemberian bantuan bagi pengembangan potensi yang ada padanya dan atau penyelesaian masalah-masalah yang dihadapinya.

Mahasiswa dikatakan memahami jika mereka dapat mengkonstruksi makna dari pesan-pesan pembelajaran, baik yang bersifat lisan, tulisan ataupun grafis, yang disampaikan melalui pengajaran, buku, atau layar komputer. Mahasiswa memahami ketika mereka menghubungkan pengetahuan 'baru' dan pengetahuan lama mereka. Lebih tepatnya pengetahuan baru masuk dipadukan dengan skema-skema dan kerangka-kerangka kognitif yang telah ada.

Anderson dan Krathwohl (2010: 105-115) mengemukakan bahwa siswa memahami ketika mereka menghubungkan pengetahuan "baru" dan pengetahuan lama mereka. Lebih tepatnya, pengetahuan kerangka kognitif yang telah ada. Lantaran konsep-konsep di otak seumpama blok-blok bangunan yang di dalamnya berisi skema-skema dan kerangka-kerangka kognitif, pengetahuan konseptual menjadi dasar untuk memahami. Proses kognitif memahami meliputi menafsirkan, mencontohkan, mengklasifikasikan, merangkum, menyimpulkan, membandingkan, dan menjelaskan.

Berdasarkan pre penelitian yang peneliti lakukan, didapatkan hasil bahwa terdapat perbedaan tingkat pemahaman mahasiswa dalam mengaplikasikan metode penyelesaian masalah pada materi sistem persmaan linier, sehingga peneliti ingin mengetahui lebih dalam tentang tingkat pemahaan mahasiswa dalam mengaplikasikan metode dalam menyelesaikan masalah sistem persamaan linier.

\section{Kerangka Berpikir}

Untuk mengetahui hasil
pemahaman mahasiswa dalam
mengaplikasikan metode, maka peneliti
membuat skema kerangka berpikir yaitu
sebagai berikut:




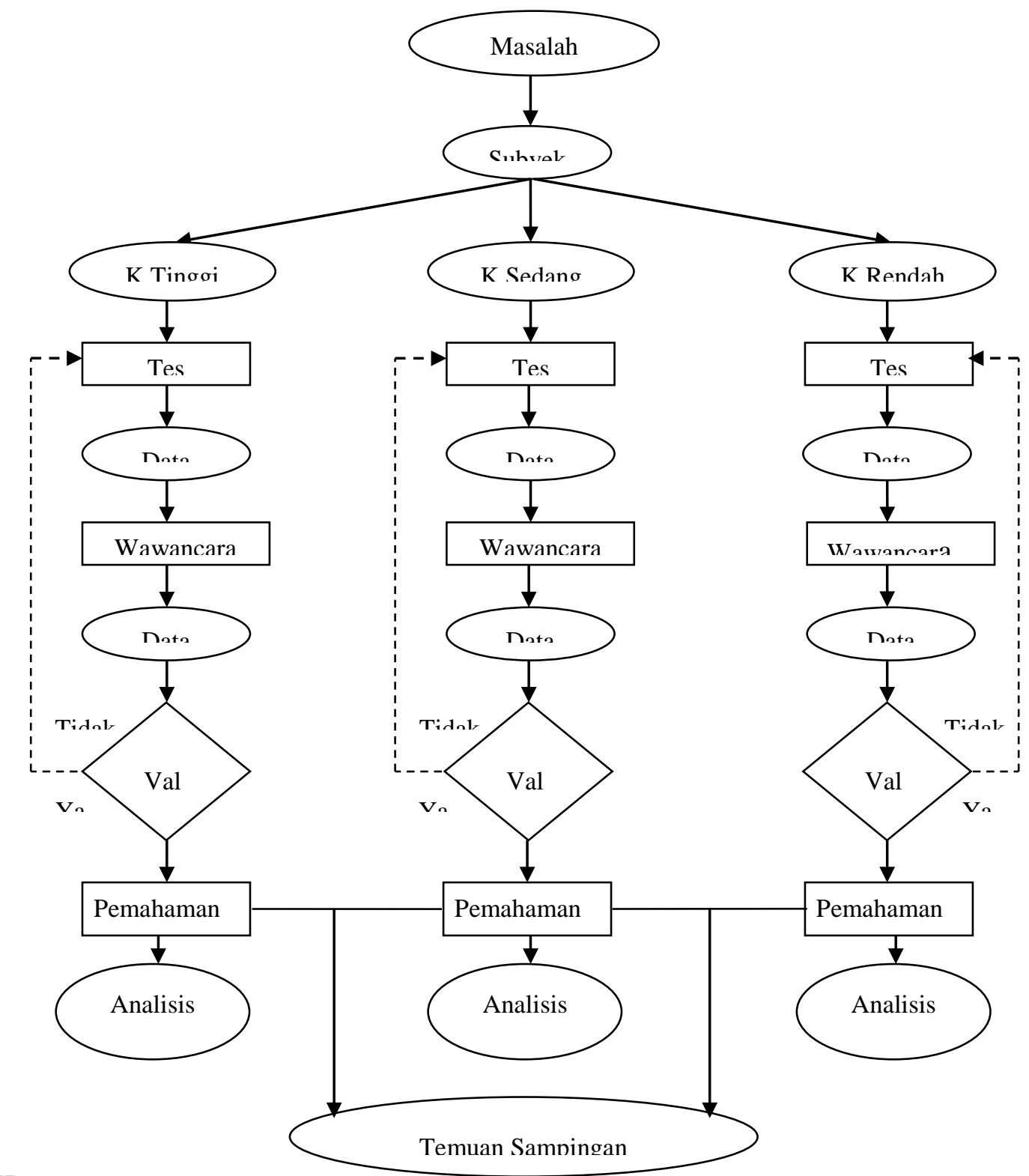

Keterangan:

1. $\bigcirc:$ Kumpulan

2. $\square$ : Melakukan kegiatan

3.

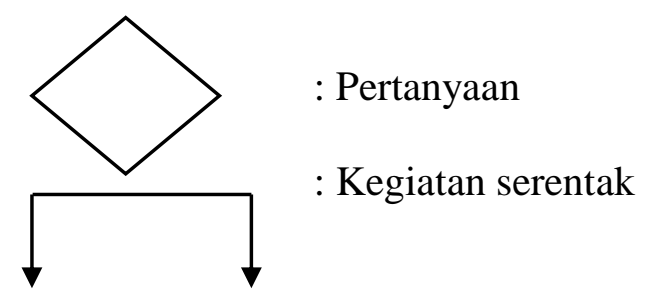

5. - _- - : Siklus jika diperlukan 


\section{METODE PENELITIAN}

Jenis penelitian ini adalah kualitatif karena akan dicari tahu tentang bagaimana pemahaman mahasiswa dalam mengaplikasikan metode, sehingga penelitian dilakukan dengan teknik tes, wawancara dan dokumentasi sehingga data yang diperoleh tidak berbentuk angka melainkan dalam bentuk kata-kata dan gambar. Data yang diperoleh akan diuraikan yang kemudian dianalisis. Sumber data dalam penelitian ini adalah kata-kata dan tindakan yang diperoleh dari hasil wawancara terhadap mahasiswa serta sumber tertulis/tes. Adapun secara rinci sumber data sebagai berikut:

1. Subyek

Pada penelitian ini pengambilan subyek hanya diambil sebagian dari subyek yang dapat mewakili subyek yang akan diteliti.Dalam penelitian ini subyek penelitianya adalah 6 mahasiswa, yang mempunyai tingkatan prestasi tinggi, sedang dan rendah.

2. Teknik Pengambilan Sampel

Pengambilan sampel dalam penelitian ini dilakukan dengan cara mengelompokkan mahasiswa berdasarkan hasil tes kemampuan kognitif.

Mahasiswa dikelompokkan menjadi tiga kelompok yaitu yang berkemampuan tinggi, rendah dan sedang.

\section{Teknik Pengumpulan Data}

Sugiyono (2010:193) menyatakan data dapat dilakukan dalam berbagai setting, berbagai sumber, dan berbagai cara. Dalam penelitian ini, teknik pengambilan data yang diambil oleh penulis adalah tes dan wawancara.

\section{Tes}

Tes serentetan pertanyaan atau latihan serta alat lain yang digunakan untuk mengukur keterampilan, pengetahuan, intelegensi, kemampuan atau bakat yang dimiliki oleh individu atau kelompok (Suharsimi Arikunto, 2010: 193). Tes yang dilakukan dalam penelitian ini berupa tes soal uraian, yaitu soal yang jawabannya menuntut mahasiswa untuk mengingat dan mengorganisasikan gagasan-gagasan atau hal-hal yang telah dipelajarinya dengan cara mengemukakan atau mengekspresikan gagasan tersebut dalam bentuk uraian tertulis.

2. Wawancara

Sugiyono (2010: 194) "wawancara digunakan sebagai teknik pengumpulan data apabila ingin melakukan studi pendahuluan untuk menemukan permasalahan yang harus diteliti, dan juga apabila peneliti ingin mengetahui hal-hal dari responden yang lebih mendalam dan jumlah respondennya sedikit/kecil".

Emzir (2011: 60) mengemukakan kelebihan dari instrumen pengumpulan data melalui wawancara sebagai berikut.

a. Wawancara merupakan instrumen yang paling baik untuk memilih dan menilai karakteristik pribadi.

b. Wawancara mempunyai manfaat yang besar dalam mengidentifikasi dan mengatasi masalah-masalah kemanusiaan khususnya masalah efektif.

c. Wawancara mempunyai manfaat yang besar dalam konsultai.

d. Wawancara membekali peneliti dengan informasi tambahan 
untuk memperkuat data yang diperoleh melalui instrumen lain.

e. Kadang-kadang peneliti menggunakan wawancara bersama-sama dengan dengan observasi untuk memperkuat validitas data yang diperoleh melalui konfirmasi.

f. Wawancara merupakan satusatunya instrumen untuk pengumpulan data pada masyarakat buta huruf.

3. Dokumentasi

Dokumentasi dari katanya dokumen, yang artinya barangbarang tertulis. Di dalam melaksanakan metode dokumentasi, peneliti meyelidiki benda-benda tertulis seperti buku-buku, majalah, dokumen, peraturan-peraturan, notulen rapat, catatan harian dan sebagainya (Suharsimi Arikunto, 2010: 201).Menurut Suharsimi Arikunto (2010: 201-202) metode dokumentasi dapat dilaksanakan dengan : (a) Pedoman dokumentasi yang memuat garis-garis besar atau kategori yang akan dicari datanya. (b) Check-list

Penelitian

menggunakan metode dokumentasi ini digunakan peneliti untuk mendapatkan data berupa photo dan daftar nilai. Hasil photo dan daftar nilai ini akan menjadi bukti bahwa peneliti benarbenar melakukan penelitian. Hal ini dikhawatirkan kalau data peneliti hilang dan data ini bisa menjadi bukti oleh peneliti.

\section{Teknik Keabsahan Data}

Di dalam penelitian ini, teknik keabsahan data menggunakan triangulasi. Triangulasi diartikan sebagai teknik pengumpulan data yang bersifat menggabungkan dari berbagai teknik pengumpulan data dan sumber data yang telah ada (Sugiyono, 2012: 83). Nilai dari teknik pengumpulan data dengan triangulasi adalah untuk mengetahui data yang diperoleh corvergent (meluas), tidak konsisten atau kontradiksi. Oleh karena itu dengan menggunakan teknik triangulasi dalam pengumpulan data, maka data yang diperoleh akan lebih konsisten, tuntas dan pasti.

Menurut Patton dalam (Sutopo, 2002: 78-82) menyatakan bahwa ada empat teknik triangulasi, yaitu:

1. Triangulasi Data

Adalah data yang sama atau sejenis, akan lebih mantap kebenarannya bila digali dari beberapa sumber data yang berbeda.

2. Triangulasi Peneliti

Adalah hasil penelitian baik data atau pun simpulan mengenai bagian tertentu atau keseluruhannya bisa diuji validitasnya dari beberapa peneliti.

3. Triangulasi Metodologi

Triangulasi ini dilakukan oleh seorang peneliti dengan mengumpulkan data sejenis tetapi dengan menggunakan teknik atau metode pengumpulan data yang berbeda.

4. Triangulasi Teoritis

Triangulasi ini dilakukan oleh peneliti dengan menggunakan perspektif lebih dari satu teori dalam membahas permasalahan yang dikaji.

Pada penelitian ini, peneliti menggunakan triangulasi data. Pada triangulasi data ini dilakukan dengan membandingkan hasil analisis jawaban mahasiswa (tes) dan hasil wawancara. 


\section{Teknik Analisis Data}

Emzir ( 2011: 85) "analisis data merupakan proses sistematis pencarian data dan pengaturan transkripsi wawancara, catatan lapangan, dan materi-materi lain yang telah anda kumpulkan untuk meningkatkan pemahaman anda sendiri mengenai materi-materi tersebut dan untuk memungkinkan anda menyajikan apa yang sudah anda temukan kepada orang lain."

Dasar penelitian ini adalah kualitatif, maka analisis datanya non statistik. Data yang muncul berupa katakata dan bukan merupakan rangkaian kata-kata. Analisis data yang dipilih penulis dalam penelitian ini berdasarkan analisis selama di lapangan Model Miles and Huberman. Analisis data dilakukan pada saat pengumpulan data berlangsung, dan setelah selesai pengumpulan data dalam periode tertentu.

Miles dan Huberman (dalam Sugiyono, 2010: 337) mengemukakan bahwa aktivitas dalam analisis data kualitatif dilakukan secara interaktif dan berlangsung secara terus menerus sampai tuntas, sehingga datanya sudah jenuh. Aktivitas dalam analisis data yaitu.

\section{Reduksi Data (Data Reduction)}

Mereduksi data berarti merangkum, memilih hal-hal yang pokok, memfokuskan pada hal-hal yang penting, dicari tema dan polanya dan membuang yang tidak perlu. Dengan demikian data yang telah direduksi akan memberikan gambaran yang lebih jelas, dan mempermudah peneliti untuk melakukan pengumpulan data selanjutnya, dan mencarinya bila diperlukan. Dalam mereduksi data, setiap peneliti akan dipandu oleh tujuan yang akan dicapai. Tujuan utama dari penelitian kualitatif adalah pada temuan.

2. Penyajian Data (Data Display)

Setelah data direduksi, maka langkah selanjutnya adalah mendisplaykan data. Dalam penelitian kualitatif penyajian data ini dapat dilakukan dalam bentuk tabel, grafik, phie chard, pictogram dan sejenisnya. Melalui penyajian data tersebut, maka data terorganisasikan, tersusun dalam pola hubungan, sehingga akan semakin mudah difahami.

Dengan mendisplaykan data, maka akan memudahkan untuk memahami apa yang terjadi, merencanakan kerja selanjutnya berdasarkan apa yang telah difahami tersebut.

3. Conclusion Drawing/verification

Langkah ketiga dalam analisis data kualitatif adalah penarikan kesimpulan dan verifikasi. Kesimpulan awal yang dikmukakan masih bersifat sementara, dan akan berubah bila tidak ditemukan buktibukti yang kuat yang mendukung tahap pengumpulan data berikutnya. Tetapi apabila kesimpulan yang dikemukakan pada tahap awal, didukung oleh bukti-bukti yang valid dan konsisten saat peneliti kembali ke lapangan mengumpulkan data, maka kesimpulan yang dikemukakan merupakan kesimpulan yang kredibel.

Dalam mengambil kesimpulan, peneliti memfokuskan pada profil pemahaman mahasiswa dalam mengaplikasikan metode untuk menyelesaikan soal-soal trigonometri. 


\section{PEMBAHASAN}

Tabel 1. Analisis Pemahaman Hasil Tes Tulis dan Wawancara

\begin{tabular}{|c|c|c|c|c|c|c|c|c|c|c|}
\hline \multirow{3}{*}{$\begin{array}{c}\begin{array}{c}\text { Sub- } \\
\text { jek }\end{array} \\
(1) \\
\end{array}$} & \multicolumn{9}{|c|}{ Proses Kognitif } & \multirow{3}{*}{$\begin{array}{c}\begin{array}{c}\text { Ketera- } \\
\text { ngan } \\
\text { Kemamp } \\
\text { uan }\end{array} \\
(10)\end{array}$} \\
\hline & \multicolumn{2}{|c|}{ Menafsir-kan } & \multirow{2}{*}{$\begin{array}{c}\begin{array}{c}\text { Men- } \\
\text { con-toh- } \\
\text { kan }\end{array} \\
(3)\end{array}$} & \multirow{2}{*}{$\begin{array}{c}\text { Mengklasi- } \\
\text { fikasikan }\end{array}$} & \multirow{2}{*}{$\begin{array}{c}\begin{array}{c}\text { Me- } \\
\text { rang- } \\
\text { kum }\end{array} \\
(5)\end{array}$} & \multirow{2}{*}{$\begin{array}{c}\text { Menyim- } \\
\text { pulkan }\end{array}$} & \multirow{2}{*}{$\begin{array}{c}\begin{array}{c}\text { Mem- } \\
\text { ban- } \\
\text { ding-kan }\end{array} \\
(7)\end{array}$} & \multicolumn{2}{|c|}{ Menjelas-kan } & \\
\hline & (2) & (3) & & & & & & (8) & (9) & \\
\hline 1 & PA1a & - & PB1a & PC1a & PD1a & PE2a & PF1a & PG1a & - & Tinggi \\
\hline 2 & - & PA2a & PB1a & PC1a & PD1a & PE2a & PF2a & - & PG2a & Tinggi \\
\hline 3 & PA1b & - & PB1b & $\mathrm{PC} 1 \mathrm{~b}$ & PD1b & PE2b & PF1b & PG1b & - & Sedang \\
\hline 4 & - & PA2b & PB1b & PC1b & PD1b & PE2b & PF2b & - & PG2b & Sedang \\
\hline 5 & PA1c & - & PB1c & PC1c & PD1c & PE2c & PF1c & PG1c & - & Rendah \\
\hline 6 & - & PA2c & PB1c & PC1c & PD1c & PE2c & PF2c & - & PG2c & Rendah \\
\hline
\end{tabular}

\section{Keterangan:}

1. Subjek 1 dan 2 merupakan subjek dengan kategori tinggi.

2. Subjek 3 dan 4 merupakan subjek dengan kategori sedang

3. Subjek 5 dan 6 merupakan subjek dengan kategori rendah.

Dari hasil analisis tes dan wawancara pada tabel di atas, dapat ditemukan pemahaman konsep bangun ruang bagi mahasiswa SMP ditinjau dari gender sebagai berikut:

1. Pada kolom (2) dan (3) dapat disimpulkan sebagai berikut:

Secara umum, dalam tahap menafsirkan belum dapat ditunjukkan perbedaan antara ke enam mahasiswa, karena antara sesama mahasiswa yang berkategori tinggi, sedang dan rendah terdapat perbedaan kode dan pemahaman, sehingga tidak dapat diambil kesimpulan, karena belum mampu menunjukkan perbedaan antara subjek yang berkategori tinggi, sedang, dan rendah.

2. Pada kolom (4) dapat disimpulkan sebagai berikut:

Secara umum, subjek dengan kategori tinggi, sedang dan rendah memenuhi proses kognitif mencontohkan. Namun terdapat perbedaan kecenderungan antara subjek kategori tinggi, sedang, dan rendah. Subjek kategori tinggi memiliki kecenderungan memberikan lebih dari satu contoh masalah trigonometri yang memenuhi kode PB1a dengan indikator baik. Hal ini menyatakan bahwa kedua subjek tersebut mempunyai pemahaman yang lebih dalam menggunakan metode yang tepat untuk menyelesaikan masalah dengan benar. Sedangkan subjek kategori sedang memiliki kecenderungan yang berbeda pula, kedua subjek dengan kategori sedang memiliki kecenderungan memberikan satu contoh masalah trigonometri yang memenuhi kode PB1b. Hal ini menyatakan bahwa kedua subjek tersebut mempunyai pemahaman yang biasa untuk memberikan contoh pada tahap memahami masalah. Sedangkan subjek kategori rendah memiliki kecenderungan dalam memahami masalah yang kurang baik. Kedua subjek kategori rendah yang memenuhi kode PB1c cenderung kurang mampu memberikan contoh masalah trigonometri, kedua subjek ini mempunyai indikator kurang. Hal ini menyatakan bahwa kedua subjek tersebut mempunyai pemahaman yang kurang dalam penggunaan metode untuk menyelesaikan masalah pada tahap 
merencanakan penyelesaian masalah. Sehingga terdapat perbedaan pemenuhan indikator antara subjek satu dengan subjek yang lain.

3. Pada kolom (5) dapat disimpulkan sebagai berikut:

Secara umum, subjek dengan kategori tinggi, sedang dan rendah memenuhi proses kognitif Mengklasifikasikan. Namun terdapat perbedaan kecenderungan antara subjek kategori tinggi, sedang, dan rendah. Kedua subjek kategori tinggi memiliki kecenderungan memberikan lebih dari satu ciri-ciri masalah trigonometri yang memenuhi kode PC1a dengan indikator baik. Hal ini menyatakan bahwa kedua subjek tersebut mempunyai pemahaman yang lebih dalam menggunakan metode yang tepat untuk menyelesaikan masalah dengan benar. Sedangkan subjek kategori sedang memiliki kecenderungan yang berbeda pula, kedua subjek dengan kategori sedang memiliki kecenderungan memberikan satu ciri-ciri masalah trigonometri yang memenuhi kode PC1b. Hal ini menyatakan bahwa kedua subjek tersebut mempunyai pemahaman yang biasa untuk memberikan contoh pada tahap merencanakan penyelesaian masalah. Sedangkan subjek kategori rendah memiliki kecenderungan dalam memahami masalah yang kurang baik. Kedua subjek kategori rendah yang memenuhi kode PC1c cenderung kurang mampu memberikan ciri-ciri masalah trigonometri, kedua subjek ini mempunyai indikator kurang. Hal ini menyatakan bahwa kedua subjek tersebut mempunyai pemahaman yang kurang dalam penggunaan metode untuk menyelesaikan masalah pada tahap merencanakan penyelesaian masalah. Sehingga terdapat perbedaan pemenuhan indikator antara subjek satu dengan subjek yang lain.

4. Pada kolom (6) dapat disimpulkan sebagai berikut:

Secara umum, subjek dengan kategori tinggi, sedang dan rendah memenuhi proses kognitif merangkum. Namun terdapat perbedaan kecenderungan antara subjek kategori tinggi, sedang, dan rendah. Kedua subjek kategori tinggi memiliki kecenderungan meringkas lebih dari satu masalah trigonometri yang memenuhi kode PD1a dengan indikator baik. Hal ini menyatakan bahwa kedua subjek tersebut mempunyai pemahaman yang lebih dalam menggunakan metode yang tepat untuk menyelesaikan masalah dengan benar. Sedangkan subjek kategori sedang memiliki kecenderungan yang berbeda pula, kedua subjek dengan kategori sedang memiliki kecenderungan mampu meringkas satu masalah trigonometri yang memenuhi kode PD1b. Hal ini menyatakan bahwa kedua subjek tersebut mempunyai pemahaman yang biasa dalam menggunakan metode yang tepat untuk menyelesaikan masalah. Sedangkan subjek kategori rendah memiliki kecenderungan dalam memahami masalah yang kurang baik. Kedua subjek kategori rendah yang memenuhi kode PD1c cenderung kurang mampu meringkas satu masalah trigonometri, kedua subjek ini mempunyai indikator kurang. 
Hal ini menyatakan bahwa kedua subjek tersebut mempunyai pemahaman yang kurang dalam penggunaan metode untuk menyelesaikan masalah pada tahap merencanakan penyelesaian masalah. Sehingga terdapat perbedaan pemenuhan indikator antara subjek satu dengan subjek yang lain.

5. Pada kolom (7) dapat disimpulkan sebagai berikut:

Secara umum, subjek dengan kategori tinggi, sedang dan rendah memenuhi proses kognitif menyimpulkan. Namun terdapat perbedaan kecenderungan antara subjek kategori tinggi, sedang, dan rendah. Kedua subjek kategori tinggi memiliki kecenderungan memprediksikan dengan tepat suatu masalah trigonometri yang memenuhi kode PE2a dengan indikator baik. Hal ini menyatakan bahwa kedua subjek tersebut mempunyai pemahaman yang lebih dalam menggunakan metode yang tepat untuk menyelesaikan masalah dengan benar. Sedangkan subjek kategori sedang memiliki kecenderungan yang berbeda pula, kedua subjek dengan kategori sedang memiliki kecenderungan mampu memprediksikan suatu masalah trigonometri yang memenuhi kode PE2b. Hal ini menyatakan bahwa kedua subjek tersebut mempunyai pemahaman yang biasa dalam menggunakan metode yang tepat untuk menyelesaikan masalah. Sedangkan subjek kategori rendah memiliki kecenderungan dalam memahami masalah yang kurang baik. Kedua subjek kategori rendah yang memenuhi kode PE2c cenderung kurang mampu memprediksikan suatu masalah trigonometri, kedua subjek ini mempunyai indikator kurang. Hal ini menyatakan bahwa kedua subjek tersebut mempunyai pemahaman yang kurang dalam penggunaan metode untuk menyelesaikan masalah pada tahap memahami masalah. Sehingga terdapat perbedaan pemenuhan indikator antara subjek satu dengan subjek yang lain.

6. Pada kolom (8) dapat disimpulkan sebagai berikut:

Secara umum, subjek dengan kategori tinggi, sedang dan rendah memenuhi proses kognitif membandingkan. Namun terdapat perbedaan kecenderungan antara subjek kategori tinggi, sedang dan rendah. Subjek 1 kategori tinggi memiliki kecenderungan menganalisis lebih dari satu masalah trigonometri yang memenuhi kode PF1a dengan indikator baik. Sedangkan subjek 2 memiliki kecenderungan menjodohkan lebih dari satu masalah trigonometri dalam suatu kalimat matematika yang memenuhi kode PF2a. Hal ini menyatakan bahwa kedua subjek tersebut mempunyai pemahaman yang lebih dalam menggunakan metode yang tepat untuk menyelesaikan masalah dengan benar. Sedangkan subjek kategori sedang memiliki kecenderungan yang berbeda pula, subjek 3 memiliki kecenderungan dalam menganalisis satu masalah trigonometri yang memenuhi kode PF1b. Sedangkan subjek 4 memiliki kecenderungan menjodohkan satu masalah trigonometri dalam suatu kalimat matematika yang memenuhi kode PF2b. Hal ini menyatakan 
bahwa kedua subjek tersebut mempunyai pemahaman yang biasa untuk menyelesaikan masalah pada tahap merencanakan penyelesaian masalah. Sedangkan subjek kategori rendah memiliki kecenderungan dalam memahami masalah yang kurang baik. Subjek 5 yang memenuhi kode PF1c cenderung kurang mampu menganalisis masalah trigonometri, sedangkan subjek 6 yang memenuhi kode PF2c kurang mampu menjodohkan masalah trigonometri dalam suatu kalimat matematika, kedua subjek ini mempunyai indikator kurang. Hal ini menyatakan bahwa kedua subjek tersebut mempunyai pemahaman yang kurang dalam penggunaan metode untuk menyelesaikan masalah pada tahap merencaknakan penyelesaian masalah. Sehingga terdapat perbedaan pemenuhan indikator antara subjek satu dengan subjek yang lain.

7. Pada kolom (9) dan (10) dapat disimpulkan sebagai berikut:

Secara umum, dalam tahap menjelaskan belum dapat ditunjukkan perbedaan pemahaman antara ke enam mahasiswa, karena antara sesama mahasiswa yang berkategori tinggi, sedang dan rendah terdapat perbedaan kode dan pemahaman, sehingga tidak dapat diambil kesimpulan, karena belum mampu menunjukkan perbedaan antara subjek yang berkategori tinggi, sedang, dan rendah.

\section{SIMPULAN}

Berdasarkan hasil penelitian analisis kesalahan yang telah dilakukan mahasiswa kelas X-8 MAN 2 Madiun dalam mengaplikasikan metode untuk menyelesaikan masalah pada materi trigonometri berdasarkan langkah Polya dengan kategori mahasiswa tinggi, sedang, dan rendah, maka kesimpulan yang dapat diambil dari penelitian ini adalah sebagai berikut:

1. Dalam memahami masalah, mahasiswa kategori tinggi dalam memahami dan menggunakan metode sudah cukup baik, sedangkan mahasiswa kategori sedang dan rendah cenderung memiliki pemahaman yang kurang dalam penggunaan metode. Semua mahasiswa kategori tinggi, sedang, dan rendah pemahaman dan pemikiran kecenderungan yang kurang baik. Sedangkan semua mahasiswa kategori tinggi, sedang, dan rendah dalam menyusun langkah-langkah untuk menyelesaikan soal cenderung memiliki pemahaman yang kurang baik dalam mengaplikasikan metode.

2. Dalam merencanakan penyelesaian masalah, mahasiswa kategori tinggi dalam mengorganisasikan metode sesuai pengetahuan dan pengalaman dalam menyelesaikan soal memiliki pemahaman yang baik, sedangkan mahasiswa kategori sedang dan rendah cenderung memiliki pemahaman yang kurang. Semua mahasiswa kategori tinggi, sedang, dan rendah dalam melakukan pemahaman dan pemikiran dalam mengaplikasikan metode memiliki kecenderungan yang kurang baik. Sedangkan semua mahasiswa kategori tinggi, sedang, dan rendah dalam mengaplikasikan metode untuk menyusun langkah-langkah penyelesaian soal cenderung 
memiliki pemahaman yang kurang baik.

3. Dalam melaksanakan penyelesaian masalah, mahasiswa kategori tinggi dalam melakukan perhitungan dan menghitung soal matematika memiliki kecenderungan yang baik dan mampu menggunakan metode dengan tepat, sedangkan mahasiswa kategori sedang dan rendah memiliki kecenderungan pemahaman yang kurang baik. Sedangkan semua mahasiswa kategori tinggi, sedang, dan rendah dalam mengunakan metode untuk menyusun langkah-langkah dalam menyelesaikan soal memiliki kecenderungan yang kurang baik.

4. Dalam memeriksa kembali hasil yang diperoleh, mahasiswa kategori tinggi dalam melakukan mengorganisasikan pengetahuan dan pengalaman penggunaan metode dalam menyelesaikan soal memiliki kecenderungan pemahaman yang baik, sedangkan mahasiswa kategori sedang dan rendah cenderung memiliki pemahaman yang kurang. Semua mahasiswa kategori tinggi, sedang, dan rendah dalam melakukan kesalahan tindakan dan pemikiran memiliki kecenderungan yang kurang baik. Mahasiswa kategori tinggi dalam melakukan perhitungan dan menghitung soal matematika memiliki kecenderungan yang baik dalam penggunaan metode, sedangkan mahasiswa kategori sedang dan rendah memiliki kecenderungan pemahaman yang kurang baik. Sedangkan semua mahasiswa kategori tinggi, sedang, dan rendah dalam mengaplikasikan metode untuk menyusun langkah-langkah dalam menyelesaikan soal memiliki kecenderungan yang kurang baik.

\section{SARAN}

Berdasarkan kesimpulan di atas, maka beberapa hal yang perlu penulis sarankan, antara lain sebagai berikut:

1. Bagi Mahasiswa

a. Untuk mencapai hasil yang baik diperlukan usaha yang sungguh-sungguh, maka sebaiknya dalam mengerjakan suatu soal tidak hanya terpacu dengan cepatnya dalam mengerjakan soal tersebut, namun yang utama adalah ketepatan dalam proses dan hasil pengerjaan soal itu.

b. Membaca adalah kunci utama belajar, begitu pula dengan pembelajaran pemecahan masalah dengan menggunakan langkah Polya dalam memecahkan masalah soal trigonometri, pemahaman dalam isi soal sangatlah penting karena akan berpengaruh pada hasil akhir.

2. Bagi Dosen

Sebaiknya dosen dalam mengajarkan matematika dapat menerapkan metode yang tepat terhadap materi yang akan diajarkan supaya pemahaman mahasiswa terhadap materi lebih optimal.

3. Bagi Peneliti Lain

Bagi peneliti lain yang tertarik melakukan penelitian yang sejenis tentang profil pemahaman mahasiswa dalam mengaplikasikan metode, hendaknya dilakukan penelitian lebih lanjut tentang jenisjenis pemahaman untuk mengetahui pemahaman mahasiswa dalam mengerjakan soal matematika dan 
melakukan observasi lebih lanjut untuk mendapatkan mahasiswa yang pantas dijadikan subjek dalam penelitian sesuai dengan prestasi mahasiswa di sekolah.

4. Kelemahan dan keterbatasan

Dalam penelitian ini peneliti belum mampu menunjukkan secara umum kecenderungan pemahaman antara mahasiswa yang berkategori tinggi, sedang dan rendah. Hanya mampu menunjukan sampai tingkat kategori, karena terdapat tahap dalam indikator yang tidak dipenuhi oleh subjek.

Dalam memahami masalah, merencanakan penyelesaian masalah, melaksanakan penyelesaian masalah, dan memeriksa kembali hasil yang diperoleh dalam mengorganisasikan pengetahuan dan pengalaman untuk menyelesaikan soal, karena adanya keterbatasan pemenuhan indikator antara subjek satu dengan subjek lainnya.

\section{DAFTAR PUSTAKA}

Anderson dan Krathwohl. 2010. Kerangka Landasan Untuk Pembelajaran, Pengajaran, dan Asesmen. Terjemahan oleh Agung Prihantoro. Yogyakarta: Pustaka Pelajar

Anwar Sutoyo. 2012. Pemahaman Individu. Yogyakarta: Pustaka Pelajar

Emzir. 2011. Metodologi Penelitian Kualitatif Analisis Data. Jakarta: PT. Raja Grafindo Persada
Erman Suherman, dkk. 2003. Strategi Pembelajaran Matematika Kontemporer. Bandung: Universitas Pendidikan Indonesia

Herman Hudojo. 2005. Pengembangan Kurikulum dan Pembelajaran Matematika. Malang: UM Press

Muhammad. 2011. Pengertian Pemahaman (online). (http://id.shvoong.com/socialsciences/education/2203596pengertian-pemahaman.html, Diunduh 28 Pebruari 2013)

Mustaqim dan Abdul Wahab. 2003. Psikologi Pendidikan. Jakarta: PT. Rineka Cipta

Nana Syaodih Sukmadinata. 2009. Landasan Psikologi Proses Pendidikan. Bandung: PT. Remaja Rosdakarya

Sri Kurnianingsih, dkk. 2006. Matematika SMA. Jakarta: Gelora Aksara Pratama

Sugiyono. 2010. Metode Penelitian Pendidikan Pendekatan Kuantitatif, Kualitatif, dan $R \& D$. Bandung: Alfabeta

Sugiyono. 2012. Memahami Penelitian Kualitatif. Bandung: Alfabeta

Suharsimi Arikunto. 2010. Prosedur Penelitian Suatu Pendekatan Praktik. Jakarta: PT. Rineka Cipta

Sukirman. 2003. Matematika. Jakarta: Universitas Terbuka

Sutopo. 2002. Metodologi Penelitian Kualitatif. Surakarta: UNS Press 